\title{
ANALISIS DAN PERANCANGAN SISTEM INFORMASI AKUNTANSI PENJUALAN JASA DESAIN
}

\author{
Lianawati Cristian $^{1}$; Winarto ${ }^{2}$; Sonny ${ }^{3}$; Edith Fernando ${ }^{4}$ \\ 1, 2, 3,4 Jurusan Komputerisasi Akuntansi, Fakultas Ilmu Komputer, \\ Universitas Bina Nusantara Jln. K.H. Syahdan No. 9, Palmerah, Jakarta Barat 11480 \\ Liana_ch1309@binus.ac.id
}

\begin{abstract}
The purpose of this paper is to analyze the problems that exist in CV TVB and design systems design services on credit sales for this company. The methodology used is the method of analysis and design methods. The method of analysis is the observation techniques, interviews, and book study, while the method is to use the object oriented design. Results to be achieved is in addition to this study is useful for companies in improving the effectiveness and efficiency in the sales cycle design services but also useful as a material for researchers refrensi others who want to investigate this and similar problems.Concluding, the sales system of computerized design services from order acceptance process to printing the reports can solve problems that occur in old systems and procedures.
\end{abstract}

Keywords: information systems, accounting, sales, design

\begin{abstract}
ABSTRAK
Tujuan penulisan skripsi ini adalah menganalisi masalah-masalah yang ada pada CV TVB dan merancang sistem penjualan jasa desain secara kredit untuk perusahaan ini. Metodologi yang digunakan adalah metode analisis dan metode perancangan. Metode analisis adalah teknik observasi, wawancara, dan studi pustaka, sedangkan metode perancangan adalah menggunakan object Oriented. Hasil yang ingin dicapai adalah selain penelitian ini berguna bagi perusahaan dalam meningkatkan efektifitas dan efisiensi dalam siklus penjualan jasa desain tetapi juga berguna sebagai bahan refrensi bagi para peneliti lain yang ingin meneliti hal dan masalah yang sama. Simpulan, sistem penjualan jasa desain yang terkomputerisasi dari proses penerimaan pesanan sampai dengan pencetakan laporan dapat memecahkan masalah-masalah yang terjadi pada sistem dan prosedur yang lama.
\end{abstract}

Kata kunci: sistem informasi, akuntansi penjualan, desain 


\section{PENDAHULUAN}

Dewasa ini banyak sekali terjadi permasalahan dalam suatu perusahaan yang khususnya dalam hal Sistem Informasi perusahaan tersebut, hal tersebut mengakibatkan banyaknya kerugian yang di tanggung oleh perusahaan tersebut. Permasalahan yang terjadi adalah seperti redudansi pencatatan data, kesalahan pencatatan data, dan kurang ter-update-nya data perusahaan sehingga menghambat jalur informasi dalam perusahaan yang mengakibatkan keterlambatan dan kesalahan dalam pengambilan keputusan.

Untuk menanggulangi permasalahan-permasalahan seperti yang tertera pada paragraf di atas, banyak dari perusahaan yang mengalami hal serupa telah menggunakan Sistem Informasi yang telah terkomputerisasi. Namun konteks terkomputerisasi tersebut mempunyai cakupan yang luas, terkadang perusahaan mengartikannya hanya dengan menggunakan sistem yang sebenarnya kurang memadai untuk menyelesaikan semua permasalahan yang dihadapi dalam bidang Sistem Informasi.

Studi kasus penelitian ini pada CV TVB, di mana CV TVB adalah perusahaan jasa yang melayani variasi motif busana dan bordir. Perusahaan ini menggunakan Sistem Informasi yang kurang memadai karena tidak memiliki sarana yang diperlukan untuk mengatasi permasalahan yang telah terjadi dalam perusahaan itu. Dalam menjalankan usahanya, CV TVB menggunakan sistem manual sehingga diperlukan pengendalian yang lebih baik dengan mengubah sistem yang manual tersebut menjadi sistem yang terkomputerisasi.

Kajian teori mengenai sistem pemrosesan penjualan, menurut Hall (2001: 182-184), dapat dijelaskan sebagai berikut Proses penjualan dimulai dari pelanggan menghubungi departemen penjualan. Bentuk hubungan itu dapat melalui telepon, surat atau datang secara langsung. Departemen penjualan akan menangkap seluruh detail informasi dari kejadian tersebut dan mencatatnya pada pesanan penjualan. Sedangkan perancangan berorientasi objek menurut Mathiassen (2000: 12), "Object-Oriented Analysis and Design is a collection of general guidelines for carrying out analysis and design". Artinya analisis dan perancangan berorientasi objek adalah suatu kumpulan petunjuk umum untuk membuat analisis dan desain.

Ruang lingkup yang akan dibahas lebih lanjut meliputi beberapa hal seperti prosedur pelayanan terhadap order yang diterima; pembuatan invoice terhadap order yang diterima; penjualan jasa desain dilakukan secara kredit; laporan piutang, laporan pemesanan, laporan penjualan jasa, laporan penerimaan kas, laporan pesanan dalam proses pada tiap akhir periode serta merancang program sistem informasi akuntansi penjualan jasa desain yang digunakan untuk mendukung kegiatan penjualan perusahaan.

Tujuan dari penelitian ini adalah untuk mengidentifikasi sejauh mana sistem informasi penjualan jasa desain dapat bermanfaat bagi perusahaan, menganalisis masalah yang ada di sistem pada perusahaan ini serta merancang sistem penjualan jasa design secara kredit pada perusahaan ini.

Manfaat dari penelitian ini adalah dapat mengetahui kekurangan dan kelemahan yang ada pada sistem yang sedang berjalan sehingga dapat diatasi sebelum mengakibatkan kerugian yang lebih besar bagi perusahaan; memberikan informasi yang benar dan tepat waktu kepada pihak manajemen dalam pengambilan keputusan yang terbaik serta penelitian ini selain berguna bagi perusahaan dalam meningkatkan efektifitas dan efisiensi dalam siklus penjualan kredit 


\section{METODE PENELITIAN}

Metode yang digunakan adalah sebagai berikut. Pertama, metode analisis, yaitu studi pustaka, teknik observasi, survey terhadap sistem lama, analisis kebutuhan survey, identifikasi kebutuhan informasi, dan wawancara. Kedua, metode perancangan adalah menggunakan Object Oriented Analysis and Design (OOAD) dan Unified Modelling Language (UML). Di mana pada metode perancangan, dimulai dari pembuatan overview activity diagram, workflow table detail activity diagram, class diagram, usecase diagram, uml Class Diagram, Rancangan Laporan, dan Rancangan Layar.

\section{Teori Pendukung}

\section{Perancangan}

Perancangan kata ini umumnya dalam konteks system informasi biasanya mengikuti kata analisis yang didalam bahasa inggris biasa dikenal dengan istilah Information Systems Analysis and Design di mana menurut O’brein (2003: 511) perancangan berarti pengembangan secara spesifik dari hasil analisis kebutuhan untuk hardware, software, orang orang, jaringan dan data serta produk informasi yang dapat memenuhi persyaratan fungsional dari suatu system.

\section{Pengertian dan Jenis Transaksi Sistem Informasi Akuntansi}

Menurut Jones dan Rama (2006: 5), "accounting information system is a subsystem of a management information system (MIS) that provides accounting and financial information as well as other information obtained the routine processing of accounting transactions. Yang berarti sistem informasi akuntansi adalah subsistem dari sistem informasi manajemen yang menyediakan informasi akuntansi dan keuangan juga informasi lainnya yang didapatkan dari pemrosesan transaksi akuntansi rutin.

Menurut Jones dan Rama (2006: 4), jenis-jenis transaksi dalam sistem informasi akuntansi dibagi menjadi tiga. Pertama, an acquisition (purchasing) cycle, "the process of purchasing and paying for goods or services". Yang artinya siklus aquisision adalah proses pembelian barang dan service dan pengeluaran kas. Kedua, a conversion cycle, "the process of transforming aquired into goods and services". Yang artinya siklus konversi adalah suatu proses dalam mengubah barang setengah jadi menjadi barang jadi. Ketiga, a revenue cycle, "the process of providing goods or services to customers and collecting cash". Yang artinya siklus penerimaan adalah suatu proses yang memberikan barang atau jasa dari penjualan ke konsumen dan penerimaan kas.

\section{Sistem Informasi}

O’brien, James A. (2005: 28) mendefiniskan sistem informasi sebagai “An organized means of collecting, entering, and processing data, and of storing, managing, controlling, and reporting information so that an organization can achieve its objectives and goal.” Jones dan Rama (2006) mendefinisikan sistem informasi sebagai "A man made system that generally consists of an integrated set of computer-based and manual components establish to collect, store, and manage data, and to provide output information to users."

Sistem informasi, dari dua definisi di atas dapat ditarik garis besar sebagai integrasi suatu cara terorganisir (mengumpulkan, memasukkan, dan memroses data, mengendalikan, dan menghasilkan informasi dengan berbasis proses manual atau komputer untuk mencapai sasaran dan tujuan organisasi. 


\section{OOAD}

Menurut Mathiassen (2000: 12), “Object-Oriented Analysis and Design is a collection of general guidelines for carrying out analysis and design". Artinya analisis dan perancangan berorientasi objek adalah suatu kumpulan petunjuk umum untuk membuat analisis dan desain.

\section{Unified Modelling Language (UML)}

Menurut Jones dan Rama (2006: 60), UML is a language used for specifying, visualizing, constructing, and documenting an information system. Artinya UML adalah suatu bahasa yang digunakan untuk menspesifikasikan, memvisualisasikan, membangun, dan mendokumentasikan suatu sistem informasi.

\section{Use Case Diagram}

Menurut Jones dan Rama (2006: 267), "Use case diagram is a list of use cases that occur in an application and that indicate the actor responsible for each use case". Artinya use case diagram adalah daftar dari use case yang terjadi dalam suatu aplikasi dan itu menandakan bahwa aktor tersebut bertanggungjawab untuk masing-masing use case.

\section{Class Diagram}

Menurut Jones dan Rama (2006: 158), "UML class diagram is a diagram that can be used to document: tables in an Accounting Information System, relationships between tables, and attributes of tables". Artinya UML class diagram adalah suatu diagram yang dapat digunakan untuk dokumen: tabel dalam Sistem Informasi Akuntansi, hubungan antar tabel, dan atribut dari tabel.

\section{Activity Diagram}

Menurut Jones dan Rama (2006: 60), "UML activity diagram is a diagram that shows the sequence of activities in a process". Artinya UML activity diagram adalah suatu diagram yang menunjukkan langkah-langkah aktivitas dalam sebuah proses.

\section{Overview Diagram}

Menurut Jones dan Rama (2006: 61), "Overview diagram is a UML activity diagram that presents a high- level view of the business process by documenting the key events, the sequence of these events, and the information flows between these events”. Artinya overview diagram adalah kegiatan UML diagram yang memberikan tampilan tingkat tinggi pada proses bisnis dengan mendokumentasikan kejadian terpenting, rangkaian dari kejadian-kejadian dan arus-arus informasi di antara kejadian-kejadian.

\section{Detailed Diagram}

Menurut Jones dan Rama (2006: 61), "Detailed diagram is a UML activity diagram that provides a detailed representation of the activities associate with one or two of the events shown on an overview diagram". Artinya detail diagram adalah kegiatan-kegiatan UML diagram memberikan penjelasan ulang mengenai aktivitas dengan satu atau dua dari kejadian yang ditampilkan atau digambarkan oleh overview diagram.

\section{Navigation Diagram}

Menurut Mathiassen (2000: 344), "Navigation diagram is a special kind of statechart diagram that focuses on the overall dynamics of the user interface". Artinya navigasi diagram adalah sebuah jenis statechart diagram yang berfokus pada dinamika tampilan pengguna secara keseluruhan. 


\section{Basis Data (Database)}

Menurut Jones dan Rama (2006: 156), "database is a comprehensive collection of related data”. Artinya database adalah suatu kumpulan menyeluruh data yang terkait.

\section{Sistem Pemprosesan Pesanan Penjualan}

Menurut Hall (2001: 182-184), sistem pemprosesan penjualan dapat dijelaskan sebagai berikut. Pertama, proses penjualan dimulai dari pelanggan menghubungi departemen penjualan. Bentuk hubungan itu dapat melalui telepon, surat atau datang secara langsung. Departemen penjualan akan menangkap seluruh detail informasi dari kejadian tersebut dan mencatatnya pada pesanan penjualan. Kedua, langkah pertama dari proses penjualan adalah melakukan pengesahan transaksi dengan melaui proses persetujuan kredit untuk pelanggan. Ketiga, saat kredit tersebut sudah disetujui, informasi penjualan akan diteruskan ke departemen penagihan, pergudangan dan pengiriman. Keempat, langkah selanjutnya adalah mengirimkan barang dagangan, yang harus dilakukan segera setelah persetujuan kredit diperoleh. Proses pengiriman akan merekonsiliasi barang yang diterima dari gudang dengan informasi penjualan yang sudah diterima terlebih dahulu. Langkah ini digunakan untuk memastikan bahwa perusahaan mengirimkan barang yang tepat kepada pelanggan. Diasumsikan bahwa semua kondisi sudah sesuai dengan pesanan, maka barang dagangan akan dikemas dan dikirimkan melalui perusahaan angkutan umum ke pelanggan. Kemudian informasi pengiriman akan diteruskan ke proses penagihan. Kelima, proses penagihan akan mengumpulkan dokumen-dokumen yang relevan dengan transaksi tersebut (produk, harga, biaya pengurusan, angkutan, pajak dan syaratsyarat potongan harga) dan menagihkannya ke pelanggan. Informasi ini akan diteruskan ke proses piutang dan proses pengendaliaan pesediaan. Keenam, bagian piutang menerima informasi penagihan dan mencatatnya ke dalam catatan atau laporan pelanggan. Ketujuh, demikian juga, bagian pengendalian persediaan menggunakan informasi dari bagian penagihan untuk menyesuaikan data persediaan untuk menggambarkan penurunan persediaan. Kedelapan, secara berkala proses penagihan, piutang dan pengendalian persediaan melakukan perhitungan rekapitulasi dan meneruskan informasi ini ke proses buku besar umum.

Menurut clifft, saran tentang teknologi yang dirancang suatu perusahaan untuk meningkatkan penjualan dan pelayanan pelanggan sangat penting seperti dikutip berikut ini.

"The technology is designed to help companies determine the value of each customer, develop customer segments based on the customer's importance, create differentiated plans for each segment, and act on them, according to PeopleSoft.”livecliff.saran@rbi.co.uk

\section{HASIL DAN PEMBAHASAN}

\section{Perancangan Sistem}

\section{Rich Picture Prosedur Penjualan Jasa Desain}




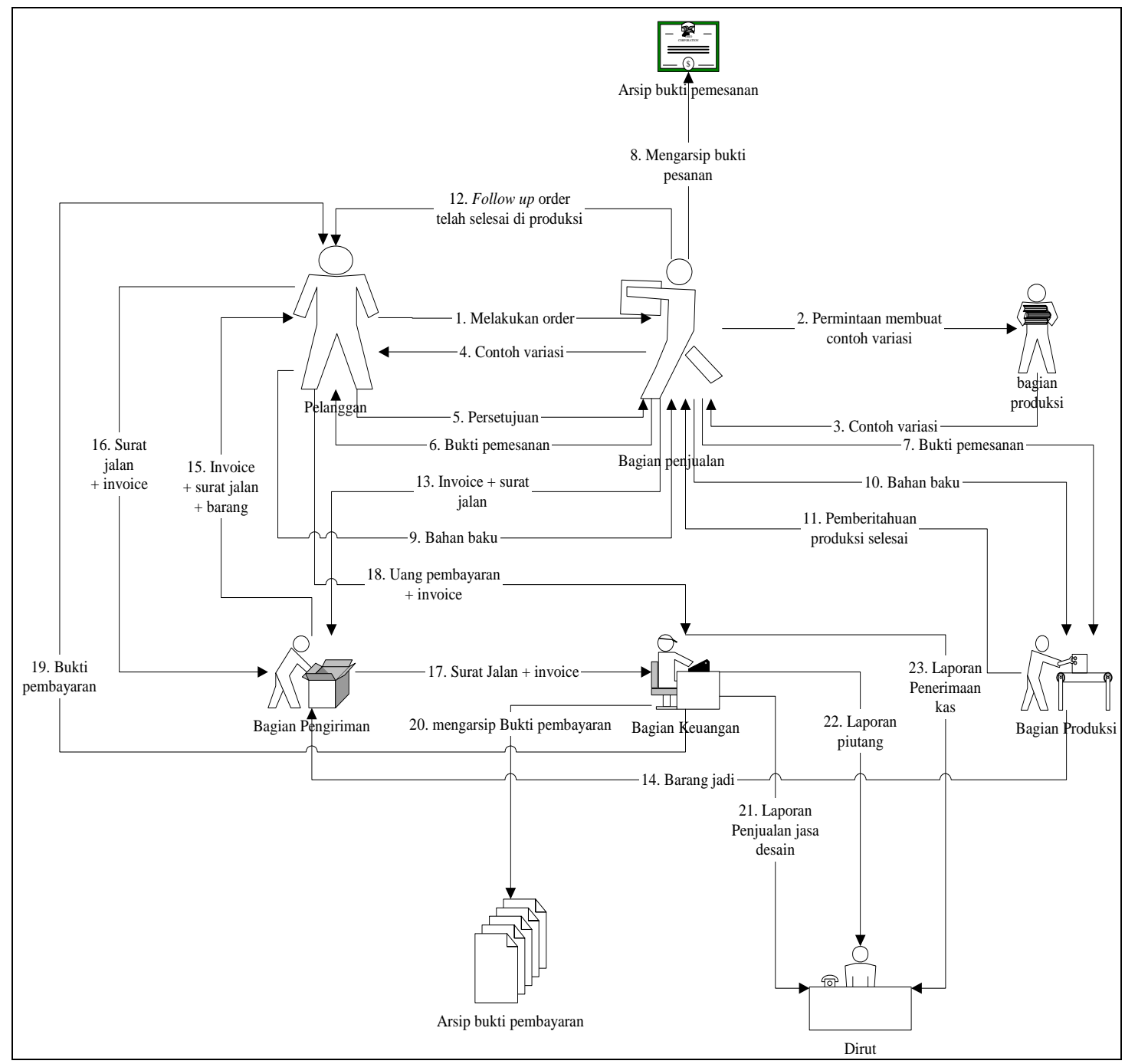

Gambar 1 Rich Picture Prosedur Penjualan Jasa Desain

\section{Keterangan Gambar 1}

Pelanggan melakukan order ke bagian penjualan, kemudian bagian produksi membuat contoh variasi desain yang dikirimkan ke pelangan.Setelah disetujui pelanggan, maka dibuat bukti pemesanan, berdasarkan bukti pesanan bagian produksi memproduksi pesanan tersebut, dengan meminta bahan baku dari gudang.

Setelah selesai produksi, maka bagian penjualan memberitahukan pelanggan, kemudian dibuat invoice dan surat jalan dikirim ke bagian pengiriman kemudian dilakukan pengiriman ke pelanggan. Copy surat jalan dan invoice dikirim ke bagian keuangan. Pelanggan menyerahkan pembayaran ke bagian keuangan. Dilakukan pencetakan laporan penjualan jasa desain dan diserahkan ke direktur.

Formulir pada sistem lama adalah bukti pemesanan, invoice, surat jalan, dan bukti pembayaran. Sedangkan laporan pada sistem lama terdiri atas: laporan penjualan jasa desain, laporan piutang, dan laporan penerimaan kas. Analisis temuan survei di dalam penelitian ini adalah permasalahan berupa seringnya mengalami kesalahan dalam pemberian nomor urut pada dokumendokumen yang diterbitkan pada setiap transaksi penjualan jasa; tidak adanya divisi khusus yang menangani penyimpanan barang hasil produksi; adanya penggabungan antara bagian keuangan dan 
bagian akuntansi; tak adanya catatan master data pelanggan serta pembuatan laporan pada akhir bulan masih dicatat secara manual.

\section{Identifikasi Kebutuhan Informasi}

Identifikasi kebutuhan informasi terdiri atas: sistem yang mencatat data pelanggan, informasiinfomasi (field) yang dibutuhkan seperti kode pelanggan, nama pelanggan, alamat, nomor telepon, dan tanggal transaksi pertama; sistem penomoran dokumen secara otomatis; sistem informasi penjualan jasa desain, sistem informasi penjualan jasa desain pada perusahaan menggunakan sistem aplikasi terkomputerisasi dalam menginput dan menerbitkan dokumen transaksi yang dibutuhkan agar pengarsipan dan penyimpanan data menjadi lebih rapi serta pembuatan laporan seperti laporan pemesanan, laporan penjualan jasa desain, laporan pesanan dalam proses, laporan piutang, laporan penerimaan kas, jurnal pembayaran, jurnal pendapatan diterima di muka, dan jurnal penjualan jasa desain.

\section{Overview Diagram Usulan}

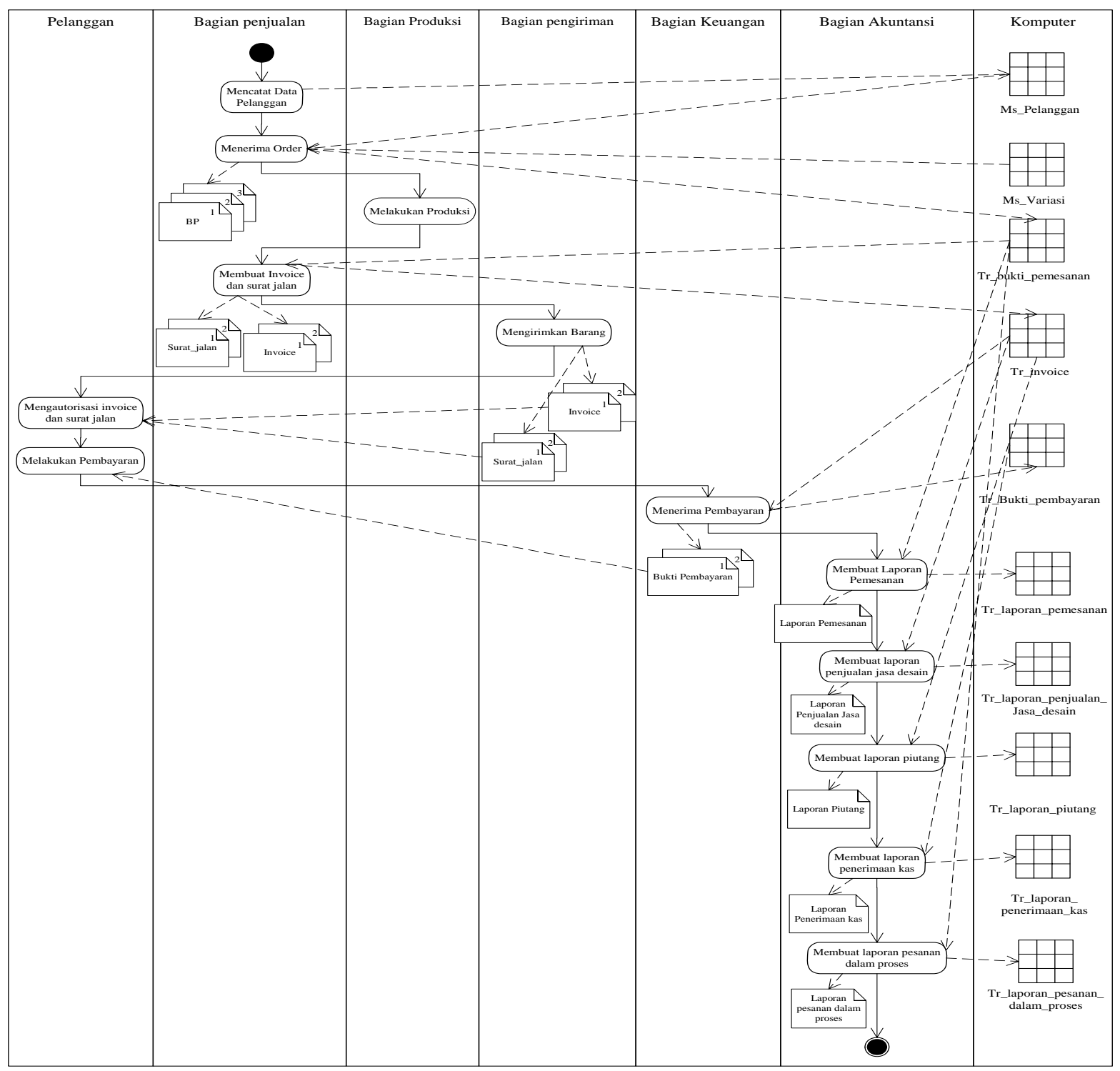

Gambar 2 Overview Activity Diagram Sistem Usulan 
UML Class Diagram Prosedur Penjualan Jasa Desain

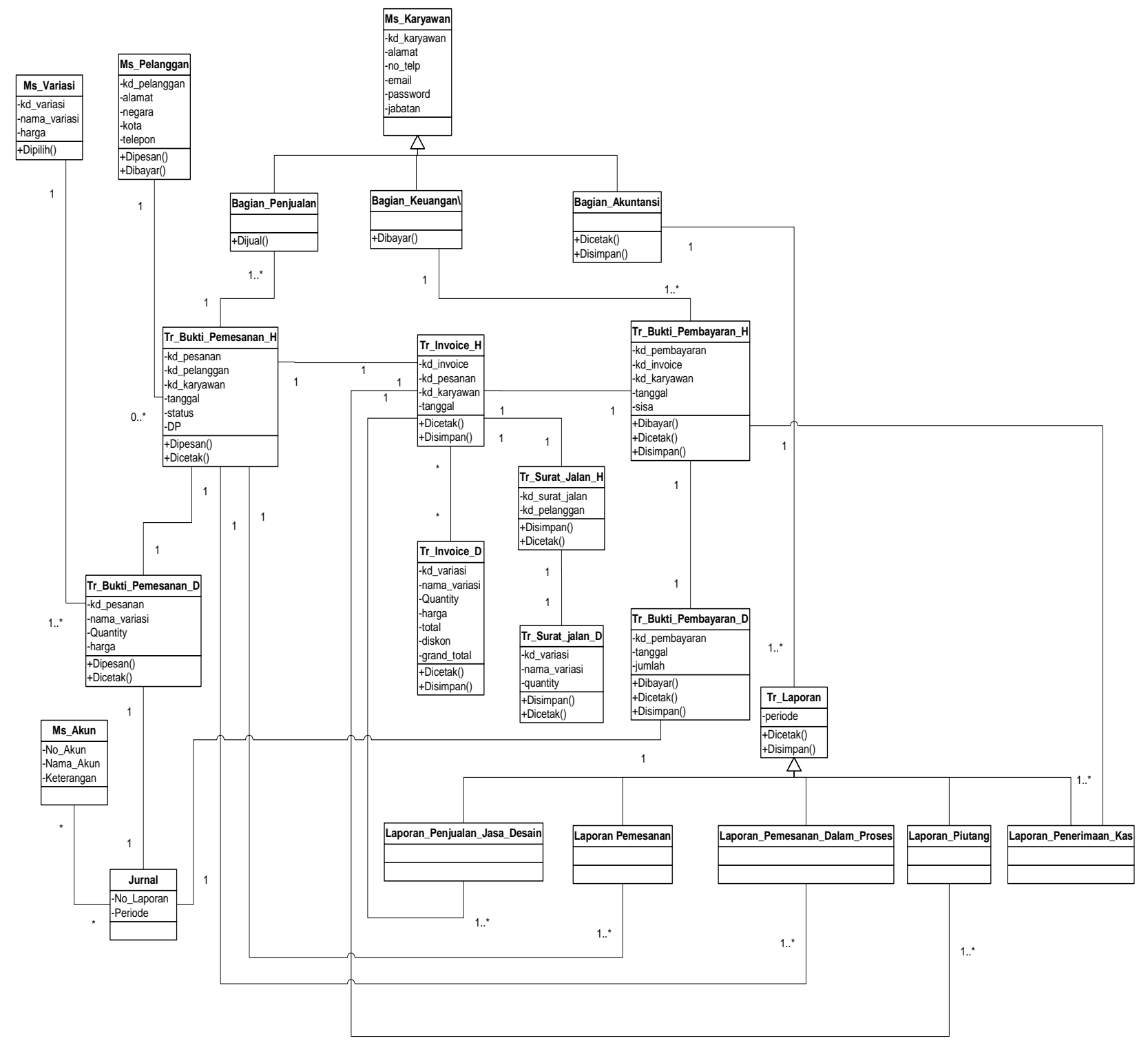

Gambar 3 UML Class Diagram Prosedur Penjualan Jasa Desain 


\section{Use Case Diagram Prosedur Penjualan Jasa Desain}

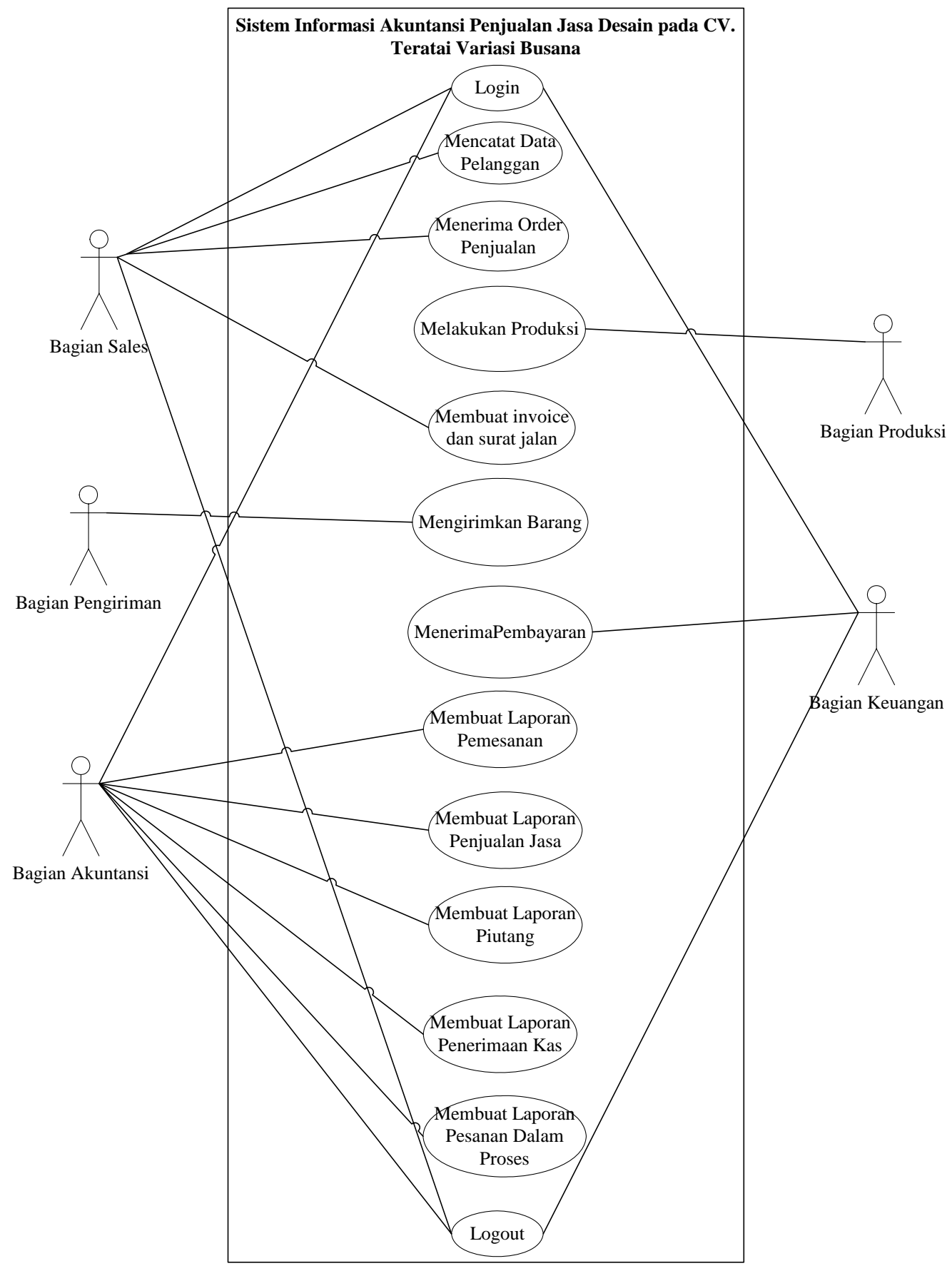

Gambar 4 Use Case Diagram Prosedur Penjualan Jasa Desain

\section{Rancangan Layar}

Berikut ini adalah contoh-contoh rancangan laporan yang ditampilkan di dalam penelitian ini, yaitu layar menu master variasi, layar menu master karyawan, layar menu master pelanggan, form pemesanan, form invoice, dan laporan penjualan jasa desain. 


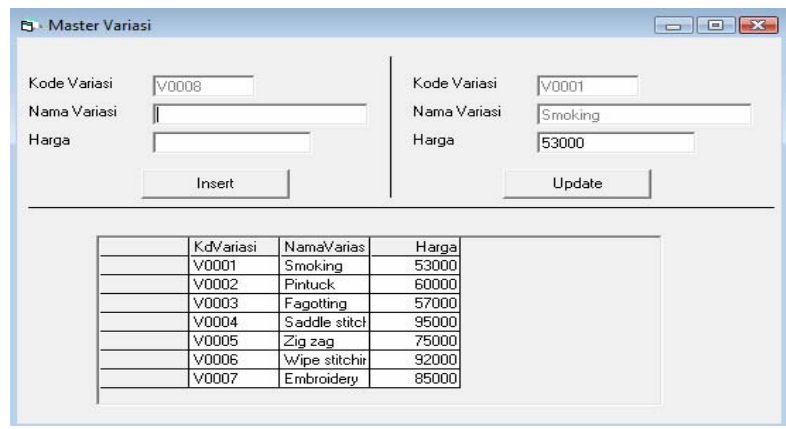

Gambar 5 Layar Menu File Master Variasi

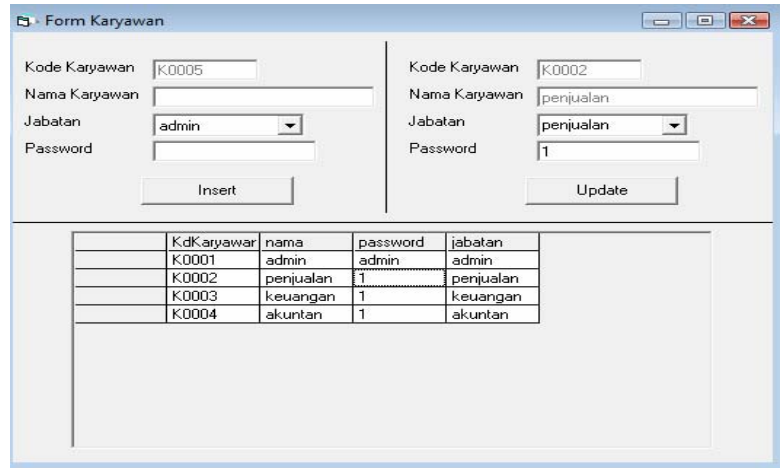

Gambar 6 Layar Menu File Master Karyawan

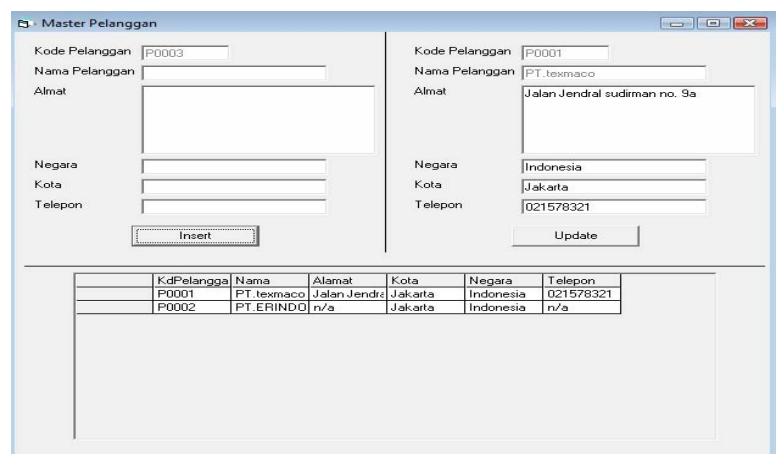

Gambar 7 Layar Menu File Master Pelanggan

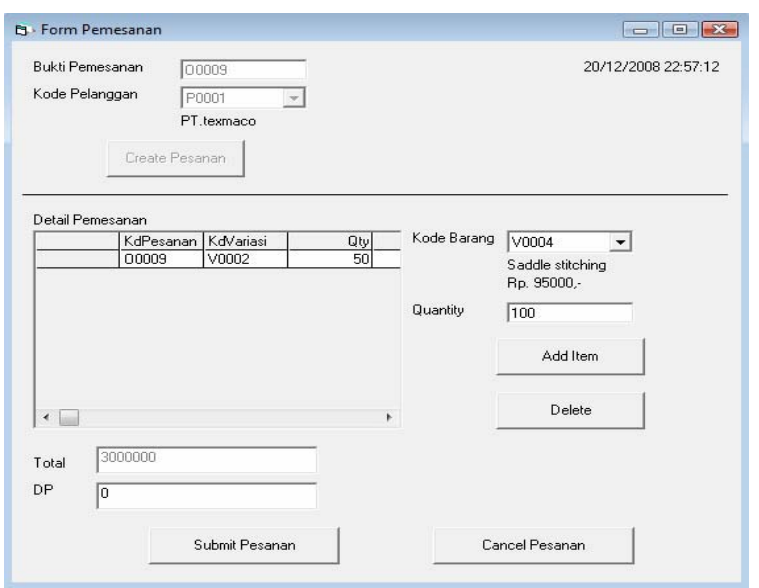

Gambar 8 Layar Menu Form Pemesanan 


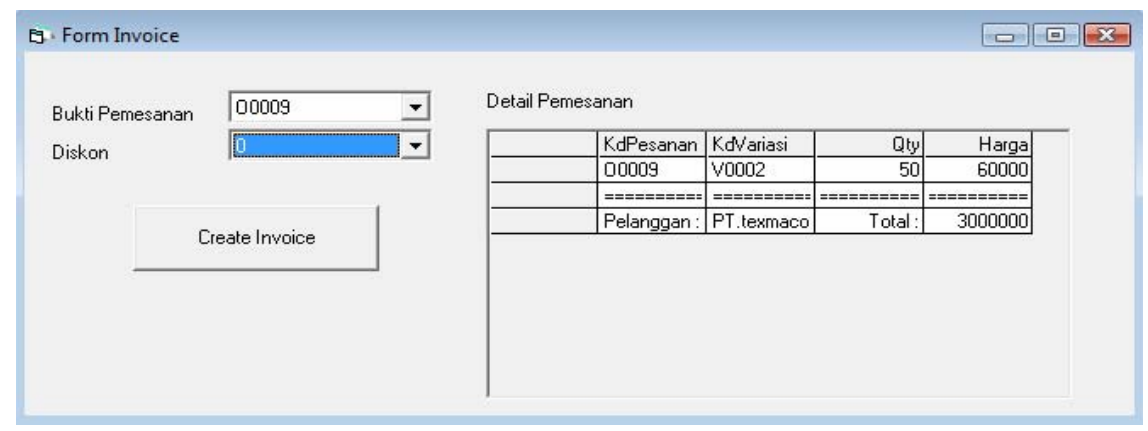

Gambar 9 Layar Menu Form Invoice

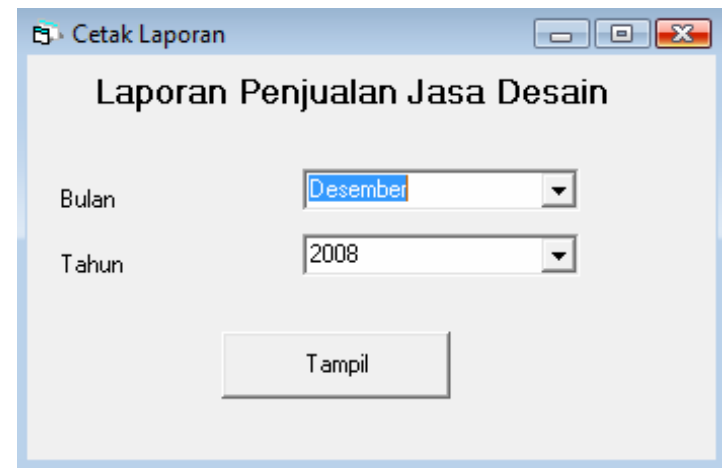

Gambar 10 Layar Laporan Penjualan Jasa Desain

\section{SIMPULAN}

Berdasarkan pembahasan yang dilakukan sebelumnya dan hasil analisis dan perancangan sistem informasi akuntansi penjualan jasa desain, maka dapat disimpulkan beberapa hal sehubungan dengan sistem informasi perusahaan sebagai berikut. Pertama, pencatatan yang dilakukan secara manual karena perusahaan tidak menggunakan sistem aplikasi yang terkomputerisasi, maka dirancanglah sebuah sebuah sistem informasi yang berbasis komputer yang dapat menangani kelemahan-kelemahan tersebut sehingga sistem informasi penjualan jasa desain akan menjadi lebih efektif dan efisien. Kedua, tidak adanya divisi khusus yang menangani penyimpanan barang hasil produksi, diusulkan adanya devisi khusus yang mengangani penyimpanan barang hasil produksi. Ketiga, adanya penggabungan antara bagian keuangan dan bagian akuntansi. Sebaiknya perusahaan memberikan job description yang jelas kepada karyawan, oleh karena itu pada rancangan sistem informasi akuntansi penjualan jasa desain yang baru terdapat sebuah layar login, di mana seorang user harus melakukan login terlebih dahulu sebagai otorisasi yang sah sehingga informasi-informasi yang ada pada perusahaan hanya dapat diakses oleh orang-orang yang berwenang atau berkepentingan. Keempat, tak adanya catatan data pelanggan, sistem yang diusulkan tersedia master pelanggan. Kelima, pembuatan laporan yang terkomputerisasi sehingga dapat lebih tepat waktu dan akurat. 


\section{DAFTAR PUSTAKA}

Hall, J. A. (2001). Sistem informasi manajemen, buku pertama, Jakarta: PT Salemba Empat.

Jones, F. L., and Rama. (2006). Accounting information systems, international student edition, Thomson South-Western.

Mathiassen, L., Madsen, Andreas M., Nielsen, P. A., and Stage, J. (2000). Object oriented analysis and design, $1^{\text {st }}$ ed., Denmark: Forlaget Marko.

Mulyadi. (2001). Sistem akuntansi, edisi ketiga, Jakarta: Salemba Empat.

O’Brien, J. A., and Marakas, G. M. (2006). Management information system, $7^{\text {th }}$ ed., New York: McGraw-Hill.

Warren, C. S., Reeve, J. M., and Fess, P. E. (2005). Accounting, $21^{\text {st }}$ ed., Ohio: Thomson SouthWestern. 